Article

\title{
Business Power in Noisy Politics: An Exploration Based on Discourse Network Analysis and Survey Data
}

\author{
Adrian Rinscheid \\ Institute for Economy and the Environment, University of St. Gallen, 9000 St. Gallen, Switzerland; \\ E-Mail: adrian.rinscheid@unisg.ch
}

Submitted: 28 October 2019 | Accepted: 29 February 2020 | Published: 2 June 2020

\begin{abstract}
This study links voter-centred and interest group perspectives to assess the role structurally powerful businesses can play in contested political issues. Revisiting the literature on business influence in politics, incumbent businesses are theorised to strategically use their structural power to influence voters' preferences. The conceptual framework is illustrated with a case study of a direct democratic vote related to Swiss energy policy. To empirically trace the role incumbent businesses played in the run-up to the vote, the study employs a two-step approach. First, it uses discourse network analysis (DNA) to examine arguments and actor coalitions in the public debate preceding the vote. Second, the DNA results inform a statistical analysis of survey data on voting behaviour. The findings suggest that incumbent businesses can use their structural power strategically to shape voting behaviour. The study stimulates the discussion about political power relationships in societies and enriches the nascent debate about phasing out unsustainable energy infrastructure. Importantly, it opens up ways to combine DNA with other methods, an avenue that shows promise for use and further refinement in future applications.
\end{abstract}

\section{Keywords}

business; discourse network analysis; direct democracy; energy; energy policy; nuclear power; phase-out; preference formation; structural power; Switzerland

\section{Issue}

This article is part of the issue "Policy Debates and Discourse Network Analysis" edited by Philip Leifeld (University of Essex, UK).

(C) 2020 by the author; licensee Cogitatio (Lisbon, Portugal). This article is licensed under a Creative Commons Attribution 4.0 International License (CC BY).

\section{Introduction}

In 2016, Swiss voters had the opportunity to stop the domestic use of nuclear power. Fuelled by the 2011 Fukushima nuclear disaster in Japan, the Green Party of Switzerland had launched a popular initiative to phase out this technology for electricity generation. The initiative provided for a gradual process of power plant closures, with the last plant to be retired by 2029 . Home to the oldest nuclear power fleet in the world, the Swiss population had formerly rejected a number of similar popular initiatives at the ballot between 1984 and 2003. Given the sustained and vocal opposition to nuclear power among parts of the population, observers viewed the Fukushima disaster as the proverbial last drop needed to make the bucket overflow, in the sense of initiating a fundamental rethink of Swiss energy policy (also in view of the substantial changes in energy policy that Switzerland's neighbouring countries Germany, Italy, and even France enacted after Fukushima). However, while polling found that a robust majority supported the popular initiative until six to eight weeks before the vote, the proposition was finally rejected by 54.2 percent of voters. How can this outcome be explained?

The politics of energy technology phase-outs have recently become a topic of interest for academic researchers (Leipprand \& Flachsland, 2018; Normann, 2019; Rosenbloom, 2018; Schreurs, 2013), as demands for phasing out energy assets that produce public 'bads' (such as nuclear waste or carbon dioxide emissions) are currently being articulated in many countries. Retiring such legacy assets might be desirable from a societal point of view, but the process comes along with concentrated losses that are mainly incurred by a relatively 
small number of actors (e.g., electric utilities and mining companies) who have benefited from previous policy choices. Therefore, these actors have a strong incentive to politically organise themselves to avert change. To organise their opposition, the expected losers of energy system changes often join forces (Kim, Urpelainen, \& Yang, 2016). In addition, they tend to rely on trade associations, peak organisations, and other political actors to influence public discourses and decisions (Barley, 2010). With respect to nuclear power, it is known that business interest groups are making considerable effort to influence public preferences and discourses (Gilbert, Sovacool, Johnstone, \& Stirling, 2017; Shrader-Frechette, 2011). However, little is known about the actual effects these activities have on people's perceptions and preferences. The controversy around the popular initiative to phase out nuclear power in Switzerland provides an opportunity for the systematic study of the arguments employed by both proponents and opponents of a nuclear phase-out in public discourse, and for exploring how the former may impact voters' decisions concerning whether to support such a proposal at the ballot box.

Conceptually, the study is anchored in broader debates about the role of business influence in politics. As Lindblom (1977) famously argued, incumbent businesses, based on their control over important economic resources, enjoy a 'privileged position' in the political system. The state's dependence on private sector profitability often allows businesses to influence political decisions. This structural power typically comes with resource advantages and privileged access to decision-makers, amplifying business influence in policymaking (Newell \& Paterson, 1998). While this perspective is helpful for understanding how businesses and business interest groups can shape political outcomes in arenas shielded from voter influence, it has less to say about business influence in noisy politics. Noisy politics refers to situations of high salience in which the preferences of attentive voters are important signposts for policymakers. Importantly, voters' initial preferences in these situations might run counter to business interests. Are businesses able to sway voters' preferences in situations of noisy politics? If so, how?

In asking these questions, the study takes up Culpepper's (2016, p. 460) call for "returning the voting public to [the] inquiry into political conflict between interest groups." While the behavioural political science literature has produced a vast body of work on the sources and effects of citizen preferences and voting behaviour, organised interests and the concept of business power are underrepresented in these accounts (Hacker \& Pierson, 2010, p. 167). Further, although much research assumes that vested interests are an important driver of voter preferences, few studies have underpinned this link empirically (Dür, 2018). As a contribution to bridging this gap, this investigation follows Emmenegger and Marx's (2019) suggestion of integrating behaviouralist and interest group perspectives and studying politics as an 'organised spectacle.' It thereby specifically focuses on the role of political discourse in which political actors exchange (and contest) their arguments, and explores the extent to which citizens' approval of prominent arguments raised by political actors relates to their voting behaviour.

\section{Business Power and Preference Formation}

\subsection{Business Power and Noisy Politics}

Lindblom (1977) argued that, compared to other political elites, business enjoys a 'privileged position' in politics. Businesses command financial and human resources and crucial knowledge that they can employ to convert their interests into political influence. As more recent research has shown, businesses have a particularly strong influence on public policies in situations of 'quiet politics.' Quiet politics refers to issues with little public scrutiny and low sustained interest from the voting public (Culpepper, 2016, p. 461). If the public does not function as a veto player, businesses can work through covert channels of influence and do not need to take partisan political incentives into account (Culpepper, 2011).

But what happens if policy issues become salient? Consider climate change, or the gender pay gap: While voters in many places have been largely indifferent to these issues over sustained periods of time, allowing businesses to dictate public policies (or the absence thereof), these issues have recently been elevated on political and media agendas. In such situations of high salience business interests are less likely to become directly converted into policy as policymakers have to attend to voters' preferences as well. This makes voters' preferences an obvious-albeit not the only-target of the political activities of businesses.

To understand the ways in which businesses may try to sway voters' preferences, the distinction between instrumental and structural power is helpful (Culpepper \& Reinke, 2014; Lindblom, 1977). Instrumental power is based on a number of strategies that businesses employ to influence the public, such as public relations campaigns or donations. Influence is less strongly assumed to be a result of persuasion, but rather to depend on the amount of resources that are deployed (Emmenegger \& Marx, 2019, p. 107). While research on the influence of financial resources in electoral politics abounds, evidence concerning the conjecture that 'money buys politics' is inconsistent at best (Walker \& Rea, 2014, p. 286).

However, some businesses also wield a structural form of power, a fact which has received far less attention in the electoral literature. A firm's structural power is the result solely of its position in the economy (Culpepper, 2016, p. 459). Structural power is assumed to constrain policymakers' room for manoeuvre automatically, because policymakers that aim at reelection need to be attentive to the impacts their policies have on short-term economic prosperity (Przeworski \& Wallerstein, 1988). Firms, according to this perspec- 
tive, influence political decisions "whether they want to or not" because their "sheer existence...leaves them no alternative" (Bachrach, 1967, p. 80). Recently, though, the deterministic drive of the structural power argument has been criticised (Bell \& Hindmoor, 2014; Culpepper, 2016). Especially in situations of noisy politics, structural power requires agency to become converted into policy. The reason for this is that many voters (unlike politicians) are likely to be uninformed about business preferences. In policy debates, businesses can therefore be expected to actively argue for their preferred courses of action. However, rather than using arguments that reflect their narrow self-interest, businesses may strategically signal what adverse effects may be expected if their preferences are not converted into policy. Such signals may be most effective when they imply tangible threats that are directly relevant to voters. Some of these arguments may be expected to resonate especially well with the population. As an example, Emmenegger and Marx (2019) show how the arguments of businesses against an inheritance tax proposal in Switzerland focused on the potentially negative effects that such a tax could have on competitiveness and jobs. Leaving aside whether such concerns were justified, what matters in such situations are voters' beliefs, and these are socially constructed (Emmenegger \& Marx, 2019, p. 107). This view of structural power assigns a strong role for agency by recognizing that the former can be deliberately used by businesses as a strategic resource (Culpepper \& Reinke, 2014). In this sense, structural power in noisy politics becomes effective only if it is aligned with discursive strategies (Levy \& Egan, 2003).

\subsection{Amplification of Power through Business-Party Alliances}

Experimental research shows that the ability of organised interests to affect voters' preferences can be very limited (Nicholson, 2011). The reason is that voters predominantly attend to arguments they perceive as credible, and the perceived credibility of an argument, in turn, depends on the communicator's trustworthiness (Page, Shapiro, \& Dempsey, 1987; Rinscheid, Pianta, \& Weber, in press)-an asset that is not necessarily one of the strengths of 'big business.' Hence, to successfully affect voters' preferences in noisy politics, businesses need strong and trustworthy allies to communicate their arguments. They typically find these allies in government and political parties and may take advantage of the fact that voters often use information about parties' positions as a simplifying heuristic when forming preferences about specific political issues (Kriesi, 2005). In noisy politics, businesses' structural power can thus be expected to be amplified through political parties.

\subsection{Preference Formation}

In contrast to mainstream assumptions, most individuals do not have clear-cut preferences with respect to most issues (Weber \& Johnson, 2009). Instead, they "carry around in their heads a mix of more or less consistent 'considerations'”' (Zaller \& Feldman, 1992, p. 585). While some of these considerations can be congruent, others may be mutually conflicting. For instance, in the context of environmental protection, voters might consider personal freedom, job security in polluting industries, and the state of the natural environment as relevant considerations. When facing a choice situation (e.g., a direct democratic vote), voters have to assign weights to these considerations to come to a decision. This is a complex task, highlighting that citizens' preferences are not predetermined by exogenous interests (Emmenegger \& Marx, 2019). Importantly, political actors, including business interest groups that have an interest in shaping voters' preferences, can strategically (re)frame an issue or emphasise specific arguments so as to raise the accessibility and perceived appropriateness of specific considerations (Chong \& Druckman, 2007). Preference construction in noisy politics is hence an 'organised spectacle' in which citizens respond to the frames and cues they receive from political elites (Emmenegger \& Marx, 2019).

To study the arguments that structurally powerful businesses employ to influence citizens' preferences regarding public policies, a case study involving a direct democratic vote in Switzerland is employed. Direct democratic votes, which are typically preceded by contested political campaigns, can provide a highly instructive setting for the study of noisy politics.

\section{The Case of Swiss Nuclear Power Politics}

The use of nuclear power has been a salient topic in Switzerland since the 1970s. While left-wing and green parties, environmental organisations and 'green' businesses (e.g., firms that invest in renewable energies) favour a nuclear-free energy system, incumbent businesses from the energy sector and beyond, industry associations, and centre-right parties have been supportive of nuclear power (Fischer, 2015). This constellation mirrors the stable line-up of two opposing political coalitions that spans environmental and energy policymaking in Switzerland as a whole (Kriesi \& Jegen, 2000; Markard, Suter, \& Ingold, 2016). Big electric utilities are structurally powerful not only because they provide jobs, invest, and pay taxes, but also due to their role as providers of critical infrastructure and electricity as a basic public service. It is worth pointing out that not all businesses are structurally powerful, though. The structural power of incumbent businesses like utilities that operate nuclear power plants differs significantly from that of newer firms that rely on more recently developed technological and business model innovations. In keeping with the conventions of the literature, I refer to business's structural power when in fact it would be more precise to talk about the structural power of incumbent businesses.

Triggered by the Fukushima crisis, the Green Party launched a popular initiative in 2011 which proposed 
to restrict the lifetime of nuclear reactors to 45 years. The proposal implied retirement of three of the five existing reactors in 2017, and the remaining ones in 2024 and 2029. In line with the polarised political constellation, and as is typically the case with popular initiatives, political parties, interest groups, businesses, and organisations representing civil society engaged in fervent competition to influence public views about the ballot proposition. The proposal was finally rejected by 54.2 percent of voters that participated in the November 2016 ballot. The rejection of a ballot proposition is not surprising per se, but the latter outcome is puzzling because studies that assessed public opinion about nuclear power after Fukushima consistently showed that a majority of Swiss citizens were opposed to the technology (Kristiansen, Bonfadelli, \& Kovic, 2016; Siegrist, Sütterlin, \& Keller, 2014; Visschers \& Siegrist, 2013; WIN-Gallup International, 2011) and were in favour of phasing out nuclear power, precisely according to the plan proposed by the Green Party (Swiss Electoral Studies 2015, 2017, p. 119). Even six to eight weeks before the vote, the ballot proposition was supported by almost 60 percent of the electorate (Gfs.bern, 2016). While observers of Swiss politics may rightly identify this development as a recurring pattern with popular initiatives, this pattern-matching provides no explanation for the outcome. I contend that any explanation of the collective preference shift needs to take the role of business power into account.

\subsection{Empirical Expectations}

Based on the conceptual priors discussed in Section 2, three expectations can be derived that guide the empirical analysis. First, during the referendum campaign incumbent businesses publicly express concern about the potentially negative effects of the proposed nuclear phase-out. Instead of pointing to their own foregone income, the concerns raised by structurally powerful businesses should entail threats of direct relevance to voters. Second, these businesses line up with political parties to overcome the problem of limited credibility and amplify their arguments in the news media, which represent the main arena for information transmission in direct democratic campaigns. Third, as a manifestation of business's structural power in the form of voting behaviour, the most salient arguments put forward by incumbent businesses and parties are predictors of voters' choices. By empirically investigating each of the three steps, the empirical analysis helps with understanding the failure of the Swiss nuclear phase-out proposal and stimulates discussion about business's ability to shape public perceptions.

\section{Empirical Analysis}

\subsection{Levels of Analysis}

Conceptually integrating interest group arguments with a behaviouralist perspective on citizen preferences im- plies that the empirical investigation needs to be attentive to different levels of analysis. The first and second steps focus on the political debate between supporters and opponents of the phase-out policy as it unfolded in the media arena. To assess the extent to which various actors tried to shape the public debate before the vote, I use discourse network analysis (DNA). The investigation is complemented with further evidence from primary and secondary sources. The third step relates to another level of analysis: For gauging the role that specific arguments played in voters' preference formation, data from a post-vote survey are analysed by means of regression analysis.

\subsection{Arguments and Actor Constellation}

\subsubsection{Method and Data}

DNA helps to systematically assess the salience of arguments in a discourse and actor constellations, such as incumbents' connections to political parties, over time (Leifeld, 2017). The first step in DNA is the qualitative or semiautomatic coding of statements in a text corpus. Based on the resulting dataset, different types of networks that may help with uncovering the structure of the underlying discourse can be generated. For example, an affiliation network is a bipartite graph that captures how actors refer to arguments either in an affirmative or in a negative way. An affiliation network can be transformed into an actor congruence network, i.e., an adjacency graph, in which actors are connected to other actors if they employ the same argument(s) in the text corpus under analysis. An actor congruence network can be useful for identifying coalitions of actors that share common understandings (Leifeld, 2016). Figure 1 illustrates the basic model of a discourse network and contains further explanations in the captions.

In Switzerland, more than 90 percent of the population regularly read printed newspapers (WEMF, 2019), and Swiss interest groups consider newspapers to be more important for their communication activities than other channels (Jentges, Brändli, Donges, \& Jarren, 2013). Newspaper articles are therefore a suitable data source for an empirical examination of the theoretical expectations developed in Section 3.1. The dataset used in this study relies on content analysis of all newspaper articles (excluding paid content and letters to the editor) that dealt substantially with the ballot proposition and were published between September 5 and November 20, 2016, in 22 Swiss newspapers (Table 2 in the Supplementary File includes the list of newspapers). This time frame corresponds to the core campaigning period before the vote took place. The dataset comprises newspapers from the two major Swiss language regions. It thereby covers all relevant quality newspapers, as well as the newspapers with the highest circulation in Switzerland (including free tabloids). This comprehensive newspaper sample includes a wide array of 

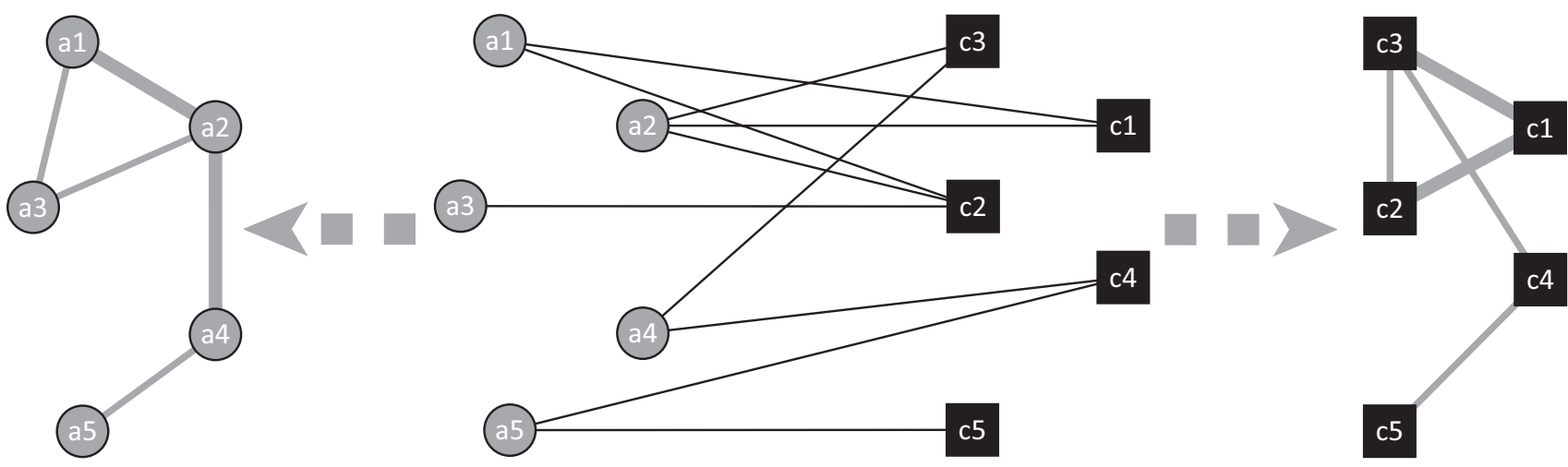

Figure 1. Basic model of a discourse network. Source: Author's own depiction based on Leifeld (2016). Notes: Circles symbolise actors and boxes symbolise arguments. The network in the middle represents an affiliation network. Here, the presence of a line indicates that a certain actor (for example, a2) mentions the linked argument (e.g., c3). The number of times an argument is mentioned in the discourse is captured by the argument's indegree centrality (e.g., indegree $=2$ for c3). Likewise, the number of arguments an actor makes is captured by the actor's outdegree centrality (e.g., outdegree $=1$ for a3). The left network illustrates the corresponding actor congruence network. In this co-occurrence network, two actors are connected if they share at least one argument in the affiliation network ( $a 1$ and a2 both mention $c 1$ and $c 2$ ). The more densely connected two actors are (depicted by line width), the more arguments they have in common. The network on the right-hand side represents the corresponding concept congruence network, where two arguments are connected if they are mentioned by the same actor ( $c 4$ and c5 are both mentioned by a5).

media with different ideological leanings, which is why the ideological bias of any individual newspapers may be only a minor issue. The dataset was compiled by the Research Institute for the Public Sphere and Society at the University of Zurich (see Udris, 2016), which since 2013 has compiled systematic datasets and analyses of newspaper reporting before all federal referenda.

In total, the text corpus includes 395 newspaper articles. The unit of analysis is the statement. Based on a coding scheme (see Table 1 in the Supplementary File), each statement made by individual or collective actors was manually encoded according to six variables:

- The date of the statement;

- The newspaper in which the statement appeared;

- The name of the actor who made the statement;

- The actor's organisational affiliation;

- The argument revealed in the statement; and

- Whether the actor approved or rejected the argument.

\subsubsection{Results}

Overall, 20 different arguments were voiced by 269 actors. The distribution of observations is relatively balanced, with 689 statements supportive of the initiative and 751 statements rejecting the ballot proposition. Table 3 in the Supplementary File details the six most frequently used arguments.

As can be seen in Figure 2, both supporters and opponents of the proposition used a broad range of arguments. The most important argument voiced by the opponents of the nuclear phase-out was the claim that the phase-out plan, which provided for a gradual phase-out by 2029 , was too 'hasty' and would lead to 'chaos' ('timing too hasty'; indegree: 104). Next, the phase-out would necessitate large-scale electricity imports, with most of the electricity coming from Germany, a country in which 40 percent of the electricity mix was generated by coalfired power plants at the time ('coal power import'; indegree: 97). This, according to opponents of the phaseout, would increase the carbon footprint of the Swiss electricity sector. Third, the pro-nuclear coalition argued that phasing out nuclear power would be 'too costly,' especially as it would lead to an increase in consumer prices ('cost of phase-out'; indegree: 78). Fourth, claims that retiring the nuclear reactors would endanger electricity supply, a key concern for many voters, also played an important role in the campaign ('endangered security of supply'; indegree: 63). Arguments about cost and security of supply can especially be interpreted as a direct manifestation of incumbents' structural power. The four most frequently mentioned arguments against the phase-out were also part of a large-scale print and online advertising campaign. Figure 3 shows an example of a poster that combines these four arguments in an emotionally appealing way by conveying the threat of supposedly imminent blackouts. The poster highlights that the findings obtained via DNA with respect to the prominence of specific arguments are not confined to the sphere of newspaper reporting. Instead, they mirror the broader communication patterns employed by the pro-nuclear coalition.

The pro-phase-out coalition focused in particular on the risks of nuclear power (Figure 2), which were mentioned frequently in the discourse ('nuclear risk'; indegree: 173). Moreover, these actors attempted to counter the argument that a nuclear phase-out would impair 


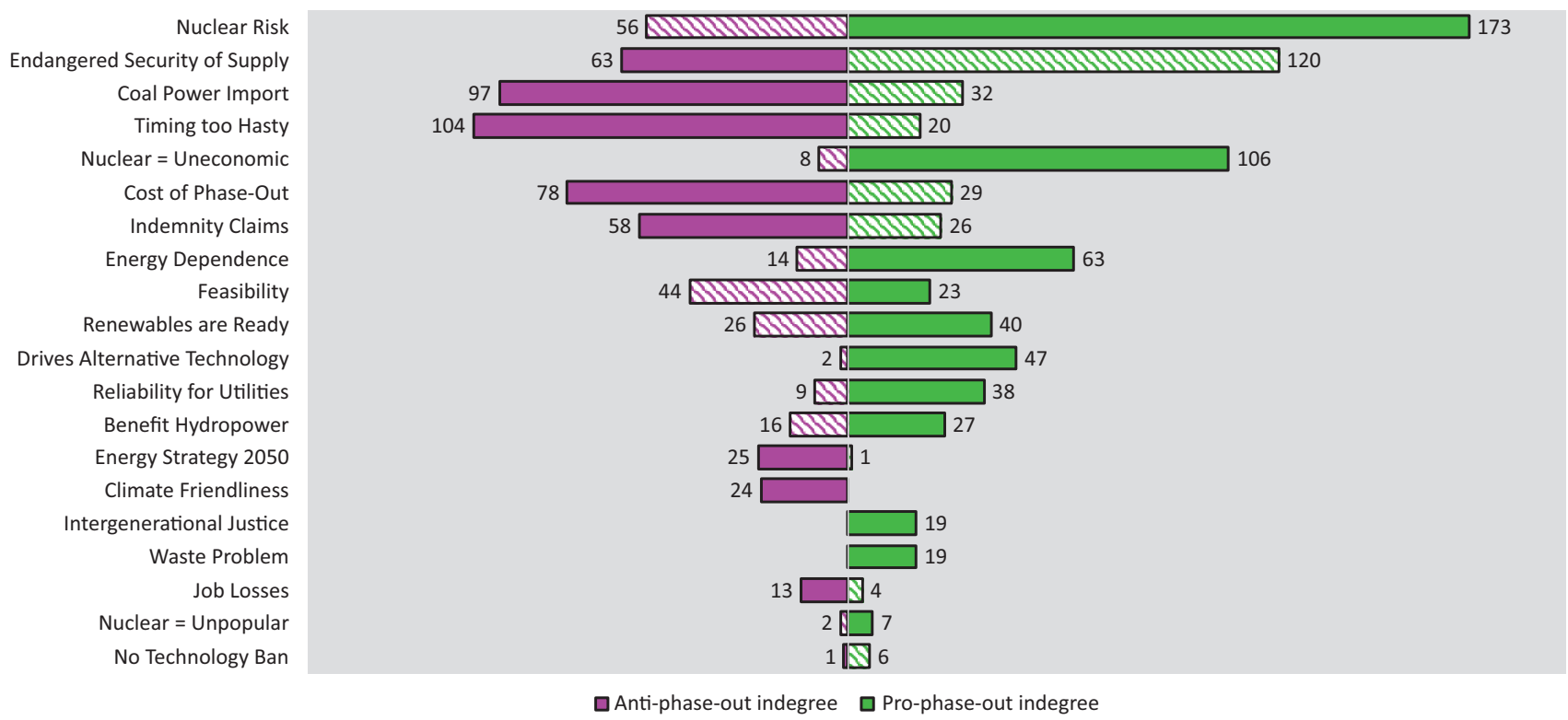

Figure 2. Bar graph showing arguments used by supporters (green bars) and opponents (purple) of the nuclear phase-out. Note: The size of the bars is proportional to the indegree centrality of the arguments. Filled bars indicate affirmative use of an argument, and patterned bars indicate negative use. For example, the argument that nuclear power is risky ('nuclear risk') was used in the affirmative sense by phase-out supporters and in the negative sense by opponents, while the argument that the phase-out would endanger security of electricity supply ('endangered security of supply') was used in the affirmative sense by phase-out opponents and in the negative sense by supporters. Based on 1,440 statements conveyed by 269 actors.

security of supply ('endangered security of supply'; indegree: 120) and portrayed nuclear power as uneconomic ('nuclear = uneconomic'; indegree: 106). Other arguments appeared considerably less frequently.

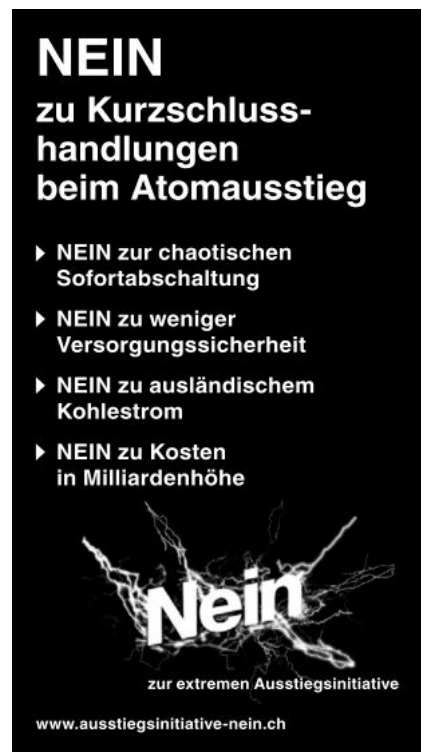

Figure 3. Anti-ballot-proposition poster. Translation: NO to rash actions in nuclear phase-out, NO to chaotic immediate shutdown, NO to reduced security of supply, NO to foreign coal electricity, NO to Billions in costs. No to the extreme nuclear phase-out initiative. Source: Ausstiegsinitiative nein (2016).
Turning to the second expectation, Figure 4 illustrates the 15 collective actors who were most active in the discourse prior to the popular vote. Among the opponents of a nuclear phase-out, the party of the Federal Councillor for Energy most actively campaigned against the ballot proposition (Christian Democratic People's Party; outdegree: 138), ahead of the conservative liberal FDP (outdegree: 77). The third most active opponent was the Axpo Group (outdegree: 50), a company that partly or fully owns three of the four Swiss nuclear power plants. Other actors that actively campaigned against the phase-out included energy utilities Alpiq and BKW Energie AG, the trade associations Economiesuisse and the Swiss Trade Association SGV, the right-wing Swiss People's Party, and the Swiss transmission network operator, Swissgrid. On the side of phase-out advocates, the Green Party (outdegree: 212) stands out as the most active actor, way ahead of other actors such as the Social Democratic Party (outdegree: 68) and the Green Liberal Party (outdegree: 42).

To illustrate how incumbent energy businesses lined up with political parties, Figure 5 depicts the actor configuration based on an actor congruence network. Here, two circles are linked if the actors which they represent share at least one argument. Closely connected clusters of circles represent coalitions of actors that share similar arguments. As can be inferred from the graph, there was clear bipolarization between supporters of the ballot proposition (represented by 119 actors on the left) and opponents (108 actors on the right). The application 


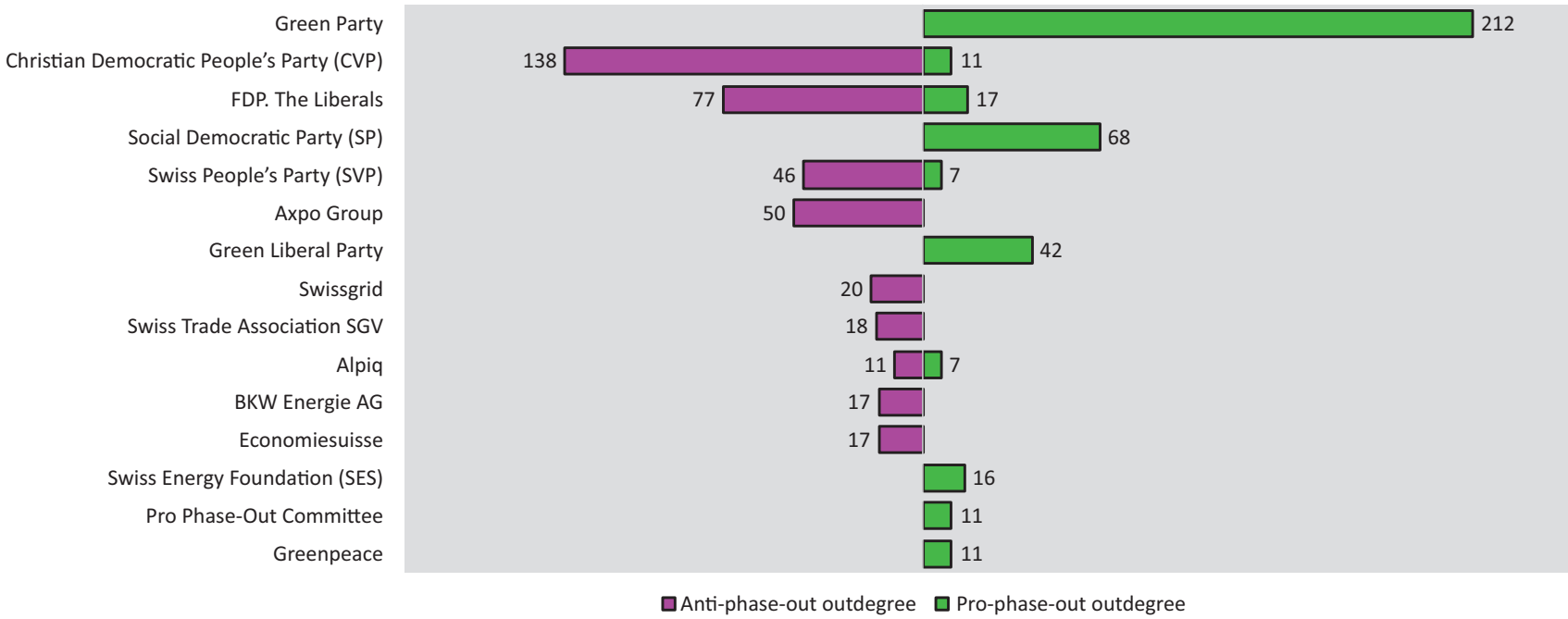

Figure 4. Bar graphs showing the 15 most active collective actors (i.e., aggregated by organisation) supporting (green bars) and rejecting (purple) the phase-out in the discourse. Note: The size of the bars is proportional to the actor's outdegree centrality. Based on 1,440 statements conveyed by 269 actors.

of the Girvan-Newman clustering algorithm, which detects coalitions by removing edges with high betweenness values, formally confirms the bipolar network structure (Girvan \& Newman, 2002).

The coalition of opponents was dominated by the big utilities (Axpo Group, Alpiq, BKW Energie AG) and several interest groups representing incumbent actors (purple circles). Moreover, these actors were well connected with the centre-right parties that opposed the proposal (blue circles). While the graph is exclusively based on shared arguments in the public discourse, the illustration mirrors Gava et al.'s (2017, p. 85) finding that Swiss business groups representing key economic sectors such as energy production have extensive interest affiliations with the parties of the political right. Going beyond an analysis of the newspaper discourse, it is known that in-

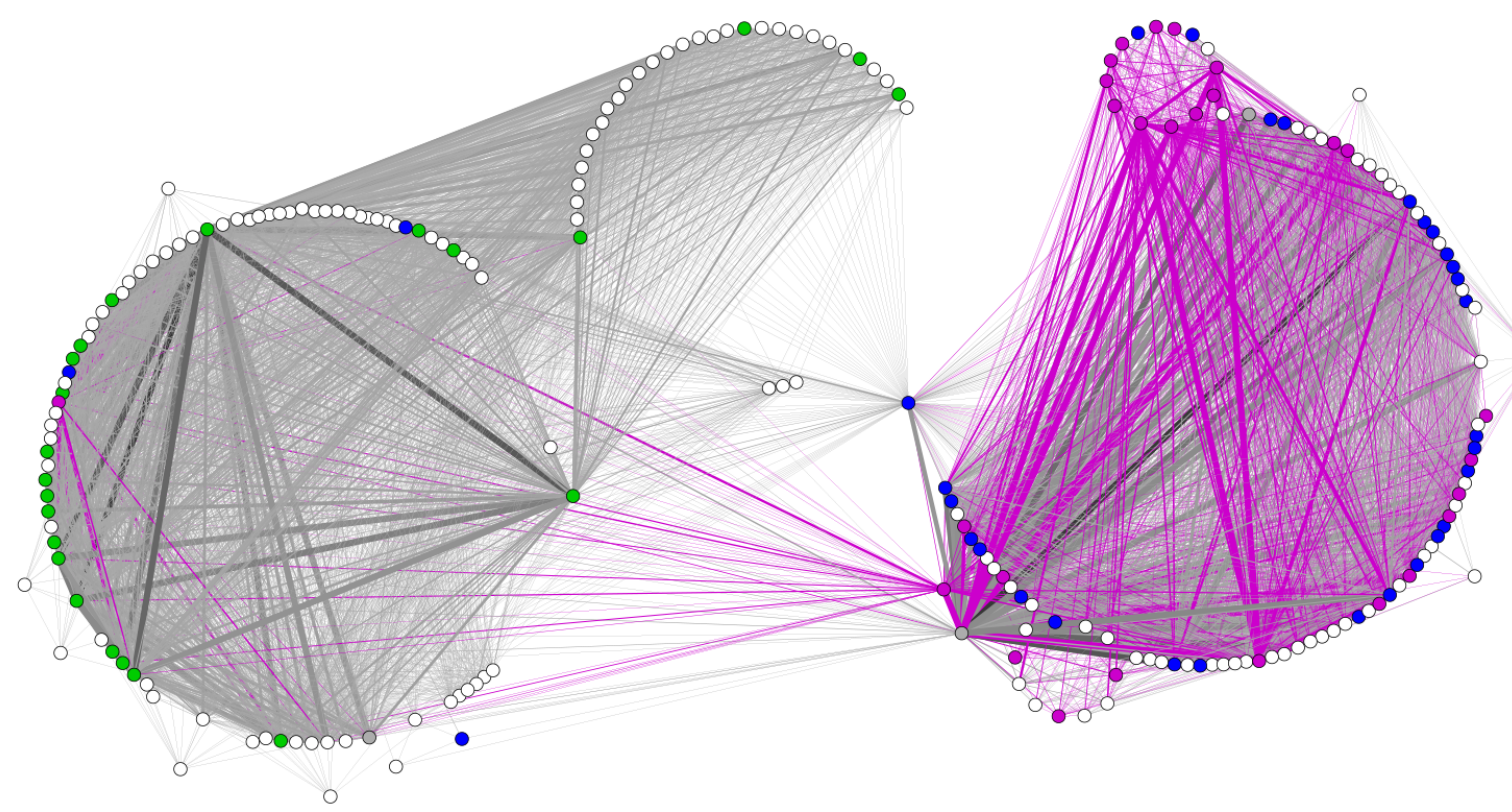

Figure 5. Actor congruence network. Note: Circles represent actors, links indicate shared arguments, and link width reflects the number of shared arguments used by connected actors. Purple circles represent actors from the nuclear utilities (Axpo Group, Alpiq, BKW Energie AG) and their interest representations, blue circles represent politicians from the parties opposing the initiative, green circles represent politicians from the parties supporting the initiative, and white circles represent other actors (e.g., municipal and cantonal authorities, scientists, etc.). All links adjacent to purple circles are also purple. Based on 1,273 statements conveyed by 227 actors. Note that these numbers are smaller than those reported in Section 4.2.2 as journalists were excluded from this network. Graph constructed with Visone 2.17 (circular layout). 
cumbent businesses and centre-right parties coordinate their campaigning efforts through so-called nonpartisan committees. These committees are typically formed in the run-up to referenda and provide businesses and political parties with an opportunity to engage in mutually beneficial resource exchange (Emmenegger \& Marx, 2019). By endorsing pro-nuclear arguments put forward by energy businesses, the parties lent credibility to incumbents' claims with respect to the purported downsides of a nuclear phase-out, while businesses provided campaign finance and expertise. In amplifying the arguments of business, the centre-right parties ultimately served to transmit business's structural power in the public arena.

\subsection{Voting Behaviour}

\subsubsection{Method and Data}

The third step of the analysis addresses whether the arguments put forward in the political debate are related to voting behaviour. As voting behaviour cannot be observed directly in the case of federal referenda, the analysis is based on a post-vote online survey fielded between November 27 (voting day) and December 1, 2016, using a representative sample $(n=1,014)$ taken from the German- and French-speaking parts of Switzerland (see Rinscheid \& Wüstenhagen, 2018, and Supplementary File for more information on the survey). The focal dependent variable is support for the ballot proposition. Of the 896 respondents who confirmed their participation in the vote, ten did not remember their decision or refused to answer the question about voting behaviour. Of the remaining $886,45.7$ percent reported they had accepted the proposition, whereas 54.3 percent indicated rejection.

To assess the role of arguments, the survey included six statements about nuclear phase-out and asked participants to state their level of agreement (measured on a five-point scale from 'fully disagree' to 'fully agree'). These statements correspond to the six arguments that appeared most frequently in the public debate (see Figure 2). Table 4 in the Supplementary File includes the wording as used in the survey. Control variables include age, gender, education, partisan orientation (using a dummy variable differentiating between parties supporting and opposing the proposition), location of voters in terms of linguistic region and whether they were living within a radius of 20 kilometres from a reactor, and the number of cars in a respondent's household as a proxy for carbon footprint (Thalmann, 2004). Table 5 in the Supplementary File includes descriptive statistics.

The survey data are analysed by means of regression analysis. In order to take voting-related self-selection into account, the analysis of the determinants of voting behaviour relies on a Heckman selection strategy (see also Carattini, Baranzini, Thalmann, Varone, \& Vöhringer, 2017). This procedure involves two steps, both based on regression analysis. First, the selection model models the process by which survey participants decided to participate in/abstain from the ballot; second, the outcome model models support for the ballot proposition as a function of both the independent variables and the estimates of step one (Johnston, 2013). In other words, the procedure jointly estimates the probability of participating in the vote (step one) and casting either a 'yes'or a 'no'-vote (step two). As both outcomes are binary, I used a probit model.

\subsubsection{Results}

Table 1 contains the model estimates. The column labelled 'Selection Model 1' presents the estimates for participation in the popular vote (i.e., step 1). Accordingly, young age (below 35) and a higher number of cars in a household are negatively related to participation. The endorsement of arguments put forward in the public debate, on the other hand, is not systematically related to turnout rates. Moreover, as an extended model contained in the Supplementary File (Table 6, Selection Model 2) shows, there is no partisan effect, which indicates that mobilization was not skewed in favour of one of the political camps. Given that the model covers only 82 non-voters, care should be taken when interpreting these findings.

Next, I turn to explaining support for the nuclear phase-out initiative as expressed through voting behaviour (i.e., step 2). According to Outcome Model 1, all six arguments introduced earlier are significant predictors of vote choice. Adding partisan orientation does not affect this finding, and partisan orientation is not significantly related to vote choice (see Outcome Model 2 of Table 6 in the Supplementary File). An additional analysis based on a series of ordered-probit models shows that partisan orientation is, at least partly, associated with approval of arguments. Hence, while there is no direct effect of partisan orientation, its impact on voting behaviour appears to be mediated by voters' approval of specific arguments. However, while voters who lean towards centre-right parties systematically endorse incumbents' arguments against nuclear phase-out, there is not much evidence for an effect of a partisan heuristic among left-wing party supporters (see Table 7 in the Supplementary File). Further factors that are correlated with voting behaviour include age, place of residence in terms of geographical proximity to a nuclear power plant, and education. While the effect for voters younger than 35 is positive, higher education and residence within the danger zone are negatively related to support for the ballot proposition.

\section{Discussion}

As outlined in Section 1, the ambition of this article is to explain the outcome of the 2016 nuclear phase-out referendum in Switzerland. By systematically assessing 
Table 1. Heckman-selection probit model explaining support for the ballot proposition.

\begin{tabular}{|c|c|c|c|c|}
\hline \multirow[b]{2}{*}{ Variable } & \multicolumn{2}{|c|}{$\begin{array}{c}\text { Outcome Model } 1 \\
(1=\text { Support for nuclear phase-out initiative })\end{array}$} & \multicolumn{2}{|c|}{$\begin{array}{c}\text { Selection Model } 1 \\
(1=\text { Participation in the vote })\end{array}$} \\
\hline & Coefficient & SE & Coefficient & SE \\
\hline \multicolumn{5}{|l|}{ Arguments against phase-out } \\
\hline Endangered security of supply & $-.477^{* *}$ & .093 & .078 & .067 \\
\hline Coal power import & $-.313^{* *}$ & .101 & .069 & .073 \\
\hline Timing too hasty & $-.524 * *$ & .093 & .009 & .068 \\
\hline Cost of phase-out & $-.437 * *$ & .088 & -.067 & .069 \\
\hline \multicolumn{5}{|l|}{ Arguments in favour of phase-out } \\
\hline Nuclear risk & $.237^{*}$ & .085 & .031 & .062 \\
\hline Nuclear $=$ Uneconomic & $.370^{*}$ & .105 & .065 & .064 \\
\hline \multicolumn{5}{|l|}{ Controls } \\
\hline Cars & -.137 & .112 & $-.134 *$ & .066 \\
\hline Young & $.707^{* *}$ & .251 & $-.316^{*}$ & .154 \\
\hline Elderly & .149 & .226 & .282 & .158 \\
\hline Female & .156 & .189 & -.158 & .125 \\
\hline Residence within Danger Zone & $-.615^{*}$ & .295 & -.163 & .159 \\
\hline French-speaking & -.358 & .219 & .085 & .166 \\
\hline Higher Education & $-.436^{*}$ & .212 & .271 & .142 \\
\hline Intercept & $3.490 * *$ & .778 & .918 & .521 \\
\hline N (censored/uncensored) & \multicolumn{4}{|c|}{$825(82 / 743)$} \\
\hline
\end{tabular}

Notes: Entries are Heckman probit coefficients and standard errors (SE). ${ }^{*} p<0.05,{ }^{* *} p<0.01$.

the arguments employed in the political discourse and the actor constellation prior to the public vote, and by using this assessment to inform an analysis of voting behaviour, the study links behaviouralist and interest group perspectives. It thereby offers an explanation for the observation that voters' perceptions of nuclear power were significantly altered in the run-up to the popular vote, as documented by Rinscheid and Wüstenhagen (2018). Going beyond the latter contribution, which was exclusively based on survey evidence, this article is interested in illuminating the role of societal actors that try to shape citizens' preferences. More generally, it contributes to a broader discussion about the structural power of business and its influence on preference formation.

The Swiss popular initiative to phase out nuclear power entailed major consequences for only a small number of firms, but the latter occupy crucial positions in the economy. Although a majority of voters initially endorsed the popular initiative, the proposal was finally rejected. The analysis suggests that structurally powerful incumbents were able to raise concerns that had a direct bearing on voters' choices. These arguments, which were amplified by centre-right parties, can be interpreted as a reflection of the structural position of incumbents in the economy. The analysis underscores Emmenegger and Marx's (2019) argument that party elites, at least in Switzerland, are often part of economic elites, so that the two are almost indistinguishable. The findings also mirror Stirling's (2014) analysis of power and knowledge in nuclear energy politics. Accordingly, the ways by which "incumbent interests configure 'scientific' knowledges such as to condition wider social expectations over what is 'realistic' or 'unrealistic' as directions for technological change" are considered a pivotal lever for influencing energy policies (Stirling, 2014, p. 86). The findings can also be related to recent research in the organizational literature, in which companies' strategy of influencing voters by expressing concern about the common good has been dubbed 'corporate citizenspeak' (Nyberg \& Murray, 2017).

It is important to note that the popular initiative was part of a broader process of reconfiguring Swiss energy policy. In 2011, the government launched a comprehensive policy package aimed at transforming the Swiss energy system. The Energy Strategy 2050 was adopted by parliament in September 2016 and obtained a popular majority in May 2017. According to the Energy Strategy 2050, nuclear power plants may be operated as long as they are considered 'safe' (while prohibiting the construction of new ones)-in contrast, the phase-out initiative followed a different logic by including specific retirement dates. Could the erosion of citizens' preferences for nuclear phase-out be simply due to a learning effect; i.e., the fact that voters became aware of the alternative proposal to prevent nuclear new build included in the Energy Strategy 2050 during the campaign in autumn 2016? The data suggest that this is unlikely, as the Energy Strategy 2050 did not play a prominent role in the discussions about nuclear phase-out in 2016 (see Figure 2, argument 'Energy Strategy 2050'). Why did energy incumbents 
manage to induce a collective preference shift in the context of nuclear phase-out, but not in the case of the Energy Strategy? The comparison points to business polarisation as an important moderating factor of business influence: Whereas incumbents and centre-right parties were united in their fight against nuclear phase-out, only some smaller pro-nuclear interest groups, sectoral associations, and the Swiss People's Party campaigned against the Energy Strategy 2050. Meanwhile, energy incumbents like Axpo Group and Alpiq, the Association of Electricity Companies, and some of the parties that were against the phase-out initiative supported the comprehensive Energy Strategy 2050.

The study responds to calls to devote more attention to the political dynamics of energy transformations (Stokes \& Breetz, 2018) and contributes to the emerging debate about the deliberate destabilization of unsustainable energy systems (Kivimaa \& Kern, 2016; Rosenbloom, 2018). The study's implications are not unique to the energy sector, though. Similar mechanisms have been shown to operate in the field of the politics of taxation, where business's structural power can explain voters' opposition to higher taxes on the super-rich (Emmenegger \& Marx, 2019). The analysis demonstrates that business's structural power requires agency to become manifest in noisy politics. Without transmission through discursive channels (i.e., campaigns that use trustworthy actors to make incumbents' arguments heard), structural power will remain ineffective.

Methodologically, one of the study's objectives was to demonstrate how the DNA method can be used to inform an analysis of survey data. Specifically, the connection of DNA and survey data analysis shows promise in terms of fostering understanding of how business power and arguments voiced in political debates influence citizens' preferences. Of course, the study also has some limitations. Most importantly, perhaps, the research design does not permit the direct testing of causal links. While the correlational evidence suggests that voters affiliated with centre-right parties considered business arguments to be credible and hence rejected the ballot proposition, experimental or panel data would be needed to provide conclusive evidence of the hypothesized mechanisms. Future work should expand this line of inquiry and try to overcome the methodological limitations of this study, for example, by combining DNA with experimental methods or linkage analysis to demonstrate the causal influence of the power of business with regard to citizens' preferences.

In addition, single-case studies raise issues of external validity. Switzerland represents an idiosyncratic institutional structure, as no other country calls its citizens to the ballot as frequently. Nevertheless, the findings suggest broader implications. First, as Emmenegger and Marx (2019, p. 116) note, apart from direct democratic votes, "ordinary elections provide similar and additional opportunities" to influence the preference formation of voters. Second, direct democratic provisions are increas- ingly being extended in many parts of the world. As this study suggests, direct democracy provides no guarantee that structural power will shrink in significance. Even if business's structural power becomes less pronounced in the traditional sense of agenda control, it may become relevant as a resource that can be strategically exploited to influence voters. Moreover, while direct democratic campaigns are an ideal laboratory for studying noisy politics, business's structural power can also push public preferences in desired directions in the absence of voting, as the business campaign against Australia's Minerals Resource Rent Tax in 2010 demonstrates (Bell \& Hindmoor, 2014).

The question whether organised interests are able to influence voters is related to the fundamental power relations in societies; notably, what Lukes (2005) introduces as the 'third face' of power. In emphasising ideational elements, this dimension of power directs attention to the possibility that some societal actors might be able to shape others' "perceptions, cognitions, and preferences in such a way that they accept their role in the existing order of things" (Lukes, 2005, p. 28). In some economic sectors, entire societies are structurally dependent on a small number of businesses, of which the energy field is an example. This study suggests that the structural position of such businesses might enable them to inculcate beliefs in others that further their own interests, but which are not necessarily to society's advantage (Pierson, 2016, p. 127). While Pierson rightly notes the methodological challenges of the related research agenda, the fact that the notion of power is absent from most studies that assess voters' preferences about public policies should not be used to commend a "shift...from a focus on individual behavior to one of strategic interaction among elites" (Pierson, 2016, p. 137). Instead, I contend that it would be more productive to connect both perspectives and to empirically assess how power relations play out in the individual-level process of preference construction. Future research may combine DNA with experimental methods or panel data to more clearly demonstrate the causal influence of the structural power of business.

\section{Acknowledgments}

This research has been conducted as part of the author's work within the Swiss Center of Competence for Energy Research SCCER CREST, Work Package IV 'Energy Governance.' The author acknowledges generous financial support by the Institute for Economy and the Environment (IWOE-HSG) at the University of St. Gallen and thanks Patrick Emmenegger, Jale Tosun, Frédéric Varone, Rolf Wüstenhagen, the two anonymous reviewers and the Academic Editor of this thematic issue for their valuable suggestions on a previous version of this article. Simon John Milton deserves credit for careful language editing. 


\section{Conflict of Interests}

The author declares no conflict of interests.

\section{Supplementary Material}

Supplementary material for this article is available online in the format provided by the author (unedited).

\section{References}

Ausstiegsinitiative nein. (2016). Ausstiegsinitiative nein. Retrieved from http://www.ausstiegsinitiative-nein. ch

Bachrach, P. (1967). The theory of democratic elitism: A critique. Boston, MA: Little Brown.

Barley, S. R. (2010). Building an institutional field to corral a government: A case to set an agenda for organization studies. Organization Studies, 31(6), 777-805.

Bell, S., \& Hindmoor, A. (2014). The structural power of business and the power of ideas: The strange case of the Australian mining tax. New Political Economy, 19(3), 470-486.

Carattini, S., Baranzini, A., Thalmann, P., Varone, F., \& Vöhringer, F. (2017). Green taxes in a post-Paris world: Are millions of nays inevitable? Environmental and Resource Economics, 68, 97-128.

Chong, D., \& Druckman, J. N. (2007). Framing theory. Annual Review of Political Science, 10(1), 103-126.

Culpepper, P. D. (2011). Quiet politics and business power: Corporate control in Europe and Japan. Cambridge: Cambridge University Press.

Culpepper, P. D. (2016). Capitalism, institutions, and power in the study of business. In O. Fioretos, T. G. Falleti, \& A. Sheingate (Eds.), The Oxford handbook of historical institutionalism (pp. 453-466). Oxford: Oxford University Press.

Culpepper, P. D., \& Reinke, R. (2014). Structural power and bank bailouts in the United Kingdom and the United States. Politics and Society, 42(4), 427-454.

Dür, A. (2018). How interest groups influence public opinion: Arguments matter more than the sources. European Journal of Political Research, 58, 514-535.

Emmenegger, P., \& Marx, P. (2019). The politics of inequality as organised spectacle: Why the Swiss do not want to tax the rich. New Political Economy, 24(1), 103-124.

Fischer, M. (2015). Collaboration patterns, external shocks and uncertainty: Swiss nuclear energy politics before and after Fukushima. Energy Policy, 86, 520-528.

Gava, R., Varone, F., Mach, A., Eichenberger, S., Christe, J., \& Chao-Blanco, C. (2017). Interests groups in Parliament: Exploring MPs' interest affiliations (2000-2011). Swiss Political Science Review, 23(1), 77-94.

Gfs.bern. (2016). 1. Welle der SRG-SSR-Trendbefragung zu den Volksabstimmungen vom 27. November 2016 [1st wave of the SRG-SSR trend survey on the popular votes on November 27, 2016]. Retrieved from http://docplayer.org/24934058-Zu-beginn-derhauptkampagne.html

Gilbert, A., Sovacool, B. K., Johnstone, P., \& Stirling, A. (2017). Cost overruns and financial risk in the construction of nuclear power reactors: A critical appraisal. Energy Policy, 102, 644-649.

Girvan, M., \& Newman, M. E. J. (2002). Community structure in social and biological networks. Proceedings of the National Academy of Sciences, 99(12), 7821-7826.

Hacker, J. S., \& Pierson, P. (2010). Winner-take-all politics: Public policy, political organization, and the precipitous rise of top incomes in the United States. Politics \& Society, 38(2), 152-204.

Jentges, E., Brändli, M., Donges, P., \& Jarren, O. (2013). Communication of political interest groups in Switzerland: Adressees, channels and instruments. Studies in Communication Sciences, 13(1), 33-40.

Johnston, C. D. (2013). Dispositional sources of economic protectionism. Public Opinion Quarterly, 77(2), 574-585.

Kim, S. E., Urpelainen, J., \& Yang, J. (2016). Electric utilities and American climate policy: Lobbying by expected winners and losers. Journal of Public Policy, 36(2), 251-275.

Kivimaa, P., \& Kern, F. (2016). Creative destruction or mere niche support? Innovation policy mixes for sustainability transitions. Research Policy, 45(1), 205-217.

Kriesi, H. (2005). Direct democratic choice: The Swiss experience. Lanham, MD: Lexington Books.

Kriesi, H., \& Jegen, M. (2000). Decision-making in the Swiss energy policy elite. Journal of Public Policy, 20(1), 21-53.

Kristiansen, S., Bonfadelli, H., \& Kovic, M. (2016). Risk perception of nuclear energy after Fukushima: Stability and change in public opinion in Switzerland. International Journal of Public Opinion Research, 28, 1-27.

Leifeld, P. (2016). Policy debates as dynamic networks: German pension politics and privatization discourse. Frankfurt and New York, NY: Campus.

Leifeld, P. (2017). Discourse network analysis: Policy debates as dynamic networks. In J. N. Victor, A. H. Montgomery, \& M. Lubell (Eds.), The Oxford handbook of political networks (pp. 301-326). Oxford: Oxford University Press.

Leipprand, A., \& Flachsland, C. (2018). Regime destabilization in energy transitions: The German debate on the future of coal. Energy Research \& Social Science, 40, 190-204.

Levy, D. L., \& Egan, D. (2003). A neo-Gramscian approach to corporate political strategy: Conflict and accommodation in the climate change negotiations. Journal of Management Studies, 40(4), 803-829.

Lindblom, C. E. (1977). Politics and markets: The world's political-economic systems. New York, NY: Basic Books. 
Lukes, S. (2005). Power: A radical view (2nd ed.). London: Palgrave Macmillan.

Markard, J., Suter, M., \& Ingold, K. (2016). Sociotechnical transitions and policy change: Advocacy coalitions in Swiss energy policy. Environmental Innovation and Societal Transitions, 18, 215-237.

Newell, P., \& Paterson, M. (1998). A climate for business: Global warming, the state, and capital. Review of International Political Economy, 5(4), 679-703.

Nicholson, S. P. (2011). Dominating cues and the limits of elite influence. The Journal of Politics, 73(04), 1165-1177.

Normann, H. E. (2019). Conditions for the deliberate destabilisation of established industries: Lessons from U.S. tobacco control policy and the closure of Dutch coal mines. Environmental Innovation and Societal Transitions, 33, 102-114.

Nyberg, D., \& Murray, J. (2017). Corporate politics in the public sphere: Corporate citizenspeak in a mass media policy contest. Business \& Society, 59(4), 1-33.

Page, B. I., Shapiro, R. Y., \& Dempsey, G. R. (1987). What moves public opinion. The American Political Science Review, 81(1), 23-44.

Pierson, P. (2016). Power in historical institutionalism. In O. Fioretos, T. G. Falleti, \& A. Sheingate (Eds.), The Oxford handbook of historical institutionalism (pp. 124-141). Oxford: Oxford University Press.

Przeworski, A., \& Wallerstein, M. (1988). Structural dependence of the state on capital. American Political Science Review, 82(1), 11-29.

Rinscheid, A., Pianta, S., \& Weber, E. U. (in press). What shapes public support for climate change mitigation policies? The role of descriptive social norms and elite cues. Behavioural Public Policy.

Rinscheid, A., \& Wüstenhagen, R. (2018). Divesting, fast and slow: Affective and cognitive drivers of fading voter support for a nuclear phase-out. Ecological Economics, 152, 51-61.

Rosenbloom, D. (2018). Framing low-carbon pathways: A discursive analysis of contending storylines surrounding the phase-out of coal-fired power in Ontario. Environmental Innovation and Societal Transitions, 27, 129-145.

Schreurs, M. A. (2013). Orchestrating a low-carbon energy revolution without nuclear: Germany's response to the Fukushima nuclear crisis. Theoretical Inquiries in Law, 14, 83-108.

Shrader-Frechette, K. (2011). Climate change, nuclear economics, and conflicts of interest. Science and En- gineering Ethics, 17(1), 75-107.

Siegrist, M., Sütterlin, B., \& Keller, C. (2014). Why have some people changed their attitudes toward nuclear power after the accident in Fukushima? Energy Policy, 69, 356-363.

Stirling, A. (2014). Transforming power: Social science and the politics of energy choices. Energy Research \& Social Science, 1, 83-95.

Stokes, L. C., \& Breetz, H. L. (2018). Politics in the U.S. energy transition: Case studies of solar, wind, biofuels and electric vehicles policy. Energy Policy, 113, 76-86.

Swiss Electoral Studies 2015. (2017). FORSbase. Retrieved from https://forsbase.unil.ch/project/studypublic-overview/13882/0

Thalmann, P. (2004). The public acceptance of green taxes: 2 million voters express their opinion. Public Choice, 119(1), 179-217.

Udris, L. (2016). Abstimmungsmonitor: Vorlage vom 27 November 2016 [Monitor on public votes: Ballot proposition from November 27, 2016]. Zurich: Research Institute for the Public Sphere and Society. Retrieved from https://www.foeg.uzh.ch/ dam/jcr:3960801b-85e5-4ef1-9a9f-9c304fdc5e6a/ Abstimmungsmonitor_November_2016.pdf

Visschers, V. H. M., \& Siegrist, M. (2013). How a nuclear power plant accident influences acceptance of nuclear power: Results of a longitudinal study before and after the Fukushima disaster. Risk Analysis, 33(2), 333-347.

Walker, E. T., \& Rea, C. M. (2014). The political mobilization of firms and industries. Annual Review of Sociology, 40, 281-304.

Weber, E. U., \& Johnson, E. J. (2009). Mindful judgment and decision making. Annual Review of Psychology, $60,53-85$.

WEMF. (2019). Total audience 2019-2: Methodik und Ergebnisse [Total audience 2019-2: Methodology and results]. Zürich: WEMF AG für Werbemedienforschung.

WIN-Gallup International. (2011). Japan earthquake and its impact on views about nuclear energy. Zurich: WIN-Gallup International. Retrieved from http:// gallup.com.pk/bb_old_site/JapanSurvey2011/ Volume\%203\%20_Japan\%20Survey_.pdf

Zaller, J., \& Feldman, S. (1992). A simple theory of the survey response: Answering questions versus revealing preferences. American Journal of Political Science, 36(3), 579-616.

\section{About the Author}

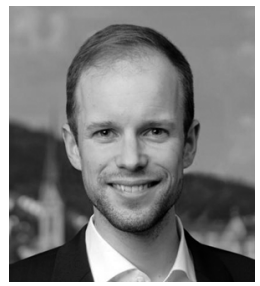

Adrian Rinscheid studied Politics and Public Administration in Konstanz (Germany) and Lyon (France), and obtained his PhD in International Affairs and Political Economy from the University of St. Gallen (Switzerland). His research interests include business-government relationships, comparative politics, and climate decision-making. His current work focuses specifically on the politics of energy system transformations, including the phase-out of unsustainable energy technologies. His work has appeared in journals like Regulation \& Governance, Climate Policy, and Nature Energy. 